\title{
Kohesivitas Kelompok Ditinjau dari Interaksi Sosial Dan Jenis Kelamin pada Anak-Anak Panti Asuhan
}

Article History:

Received

$10-09-2020$

Review

$17-11-2020$

Revised

$01-12-2020$

Accepted

$07-12-2020$

Published

$10-12-2020$

\author{
Purwaningtyastuti 1, Anna Dian Savitri ${ }^{2}$ \\ 1,2 Fakultas Psikologi Universitas Semarang \\ e-mail : ${ }^{1}$ pungkycute14@gmail.com
}

\begin{abstract}
The research that was conducted was entitled Group Cohesivity in terms of Social Interaction and Gender in Orphanages. The problem that occurs is. Children who live in the orphanage for a long time should have group cohesiveness and social interaction with the orphanage itself and its surroundings. However, what happens is that there are still many who feel uncomfortable, uncomfortable, lack of motivation, and lack of cooperation and coordination with the orphanage environment. This study aims to test empirically the relationship between social interactions with the group cohesiveness of the orphanage children and the differences in group cohesiveness between male and female children. Meanwhile, the benefit of this research is that it is hoped that it can provide input on social interactions that can create group cohesiveness for the orphanage children and for the orphanage manager, which is expected to be a reference in mentoring orphanage children with different backgrounds. The target subjects in this study were the children of the orphanage. The research method used in this research is quantitative. Collecting data in this study used a group cohesiveness scale and a scale of social interaction. Data analysis used Spearman 's rho correlation and Mann-Whitney Test. The target to be achieved is that the children of the orphanage feel more cohesive living with their group and able to interact socially well, both boys and girls. The results of this study indicate that there is a relationship between social interaction and group cohesiveness in the orphanage children. The better the social interaction, the higher the cohesiveness of the orphanage children group and vice versa so that the first hypothesis is accepted. Meanwhile, from the results of the different test, it was found that there was no difference in the group cohesiveness of the female orphanage children with the boys.
\end{abstract}

Keywords: prosocial behavior, empathy, adolescence

\begin{abstract}
Penelitian yang dilakukan ini berjudul Kohesivitas Kelompok Ditinjau Dari Interaksi Sosial dan Jenis Kelamin pada Anak-Anak Panti. Permasalahan yang terjadi adalah. anak-anak yang tinggal di panti asuhan dalam kurun waktu yang lama seharusnya memiliki kohesivitas kelompok dan interaksi sosial dengan lingkungan panti asuhan itu sendiri maupun lingkungan sekitarnya. Namun yang terjadi adalah masih saja banyak yang merasa kurang nyaman, kurang betah, kurang motivasi , dan kerjasama serta koordinasi dengan lingkungan panti yang masih dirasa kurang. Penelitian ini bertujuan untuk menguji secara empiris hubungan antara interaksi sosial dengan kohesivitas kelompok anak-anak panti asuhan dan perbedaan kohesivitas kelompok antara anak panti perempuan dan laki-laki. Sedangkan manfaat dalam penelitian ini adalah diharapkan dapat memberikan masukan mengenai interaksi sosial yang dapat mewujudkan kohesivitas kelompok bagi anak-anak panti asuhan dan bagi pengelola panti, diharapkan dapat menjadi referensi dalam pendampingan anakanak panti yang berbeda latar belakangnya. Sasaran subyek dalam penelitian ini adalah anak-anak panti asuhan. Metode penelitian yang digunakan dalam penelitian ini adalah kuantitatif. Pengumpulan data dalam penelitan ini menggunakan skala Kohesivitas kelompok dan skala interaksi sosial. Analisis data menggunakan korelasi Spearman"s rho dan Mann-Whitney Test. Target yang ingin dicapai adalah anak -anak panti asuhan lebih merasa kohesif tinggal bersama kelompoknya serta mampu berinteraksi sosial dengan baik, baik anak panti laki-laki dan perempuan. Hasil penelitian ini menunjukkan bahwa terdapat
\end{abstract}


hubungan antara interaksi sosial dengan kohesivitas kelompok pada anak-anak panti asuhan. Semakin baik interaksi sosialnya maka semakin tingg kohesivitas kelompok anak-anak panti asuhan ini dan sebaliknya sehingga hipotesis pertama diterima. Sedang dari hasil uji beda diperoleh bahwa tidak ada perbedaan kohesivitas kelompok pada anak-anak panti perempuan dengan anak-anak panti laki-laki.

Kata kunci : perilaku prososial, empati, remaja

\section{Pendahuluan}

Manusia adalah makhluk sosial. Manusia tidak akan lepas dari hidup berkelompok. Kelompok merupakan kumpulan dua orang atau lebih yang berinteraksi satu dengan yang lain dan saling pengaruh mempengaruhi. Tingkatan yang menunjukkan anggota kelompok saling tertarik satu dengan yang lain menunjuk pada kohesivitas kelompok. Dengan terbentuknya kelompok maka terjadilah interaksi diantara para anggota dalam kelompok tersebut kemudian terjadilah proses kelompok. Proses kelompok adalah merupakan interaksi antara anggota kelompok dan bagaimana pengaruh anggota kelompok satu terhadap yang lain. Bagaimana keadaan kelompok tidak ditentukan oleh motivasi, peran dari para anggotanya ataupun struktur kelompok, tetapi lebih ditentukan oleh proses kelompok tersebut. Hal ini berkaitan dengan kohesi kelompok yaitu perhatian anggota kelompok, bagaimana anggota kelompok saling menyukai satu dengan yang lain . dalam kelompok yang berlangsung lama, para anggota lebih tertarik pada kelompok tersebut daripada kelompok yang lain dan juga adanya rasa saling tertarik di antara para anggotanya. Kesamaan sikap, nilai-nilai, sifat-sifat pribadi dan juga sifatsifat demografis akan merupakan pendukung tingginya tingkat kohesi kelompok (Walgito,2003)

Demikian pula yang terjadi pada kelompok anak-anak yang tinggal di panti asuhan. Anak-anak panti asuhan yang berasal dari latar belakang keluarga yang berbeda-beda , sikap ,sifat dan nilai-nilai yang berbeda harus tinggal bersama dalam panti asuhan menjadi keluarga baru dengan bapak ibu panti. Keluarga merupakan tempat bagi individu mendapatkan pengalaman berinteraksi dan bersosialisasi pertama kalinya., menerima sosialisasi nilai-nilai dan budaya setempat dalam lingkungan primernya agar dapat tumbuh utuh secara mental, emosional dan sosial. Peran orang tua dalam keluarga sangatlah penting untuk menumbuhkan faktor psikologis anak yang terdiri dari rasa aman, kasih sayang dan harga diri. Namun tidak setiap anak beruntung dalam menjalani kehidupan sosialnya dalam keluarga.

Beberapa anak dihadapkan pada pilihan bahwa anak harus berpisah dengan orangtuanya karena suatu alasan seperti menjadi yatim, piatu, yatim piatu dan tidak memiliki sanak keluarga yang mau dan mampu mengasuhnya sehingga akhirnya terlantar. Hal ini dapat mengakibatkan kebutuhan psikologis anak tidak terpenuhi. Anak-anak yang mengalami seperti hal tersebut kemudian terlantar yang akan dipelihara oleh pemerintah atau swasta dalam suatu 
lembaga yang disebut panti asuhan. Panti asuhan inilah yang dianggap sebagai ganti keluarga oleh anak terlantar tersebut. Panti asuhan berperan sebagai pengganti keluarga dalam memenuhi kebutuhan anak dalam proses perkembangannya.Bentuk keluarga yang anak-anak miliki di panti asuhan tentunya berbeda jika dibandingkan dengan keluarga yang sesungguhnya , walaupun pada dasarnya panti asuhan bagi anak-anak asuh yang tinggal di dalamnya adalah sebuah rumah dan keluarga. Pengasuhan dan pemenuhan hak-hak sosial yang akan mereka terima juga akan berbeda. Selain itu , anak-anak panti asuhan akan menerima perlakuan yang berbeda dari lingkungan sosialnya, karena masyarakat sekitar akan memandang anak-anak panti dengan pandangan berbeda, karena anak-anak panti asuhan membawa background yang berbeda pula dari masyarakat di lingkungan mereka pada umumnya. baik itu background ekonomi mapun sosial . Terkadang masyarakat juga memberi label negatif pada anak-anak panti asuhan tanpa melihat lebih jauh, bagaimana latar belakang anak-anak panti tersebut.

Bagaimanapun anak-anak panti asuhan tetap harus berinteraksi dengan berbagai macam lingkungan sosial, baik dengan teman sepanti, dengan pengasuh panti dengan tetangga atau orang sekitar panti . Ketika berinteraksi dengan teman-teman panti, anak juga tidak terlepas dari penilaian-penilaian, pandangan dari sesama teman. karena anak-anak panti berasal dari status dan latar belakang keluarga yang berbeda beda. Hal inilah yang terkadang membuat anak-anak panti berkelompok- kelompok di dalam panti dan cenderung hanya akan berinteraksi dan peka terhadap teman satu kelompoknya saja. selain itu ada beberapa stigma yang ditujukan kepada mantan anak-anak jalanan karena dianggap yang sering membuat masalah di panti asuhan. Perlakuan yang berbeda inilah terkadang membuat beberapa anak panti merasa kurang percaya diri, menutup diri, pasif dan kurang nyaman sehingga menjadi penghambat dalam interaksi sosialnya. Pada umumnya interaksi sosial akan sulit terjadi apabila memiliki perbedaan budaya, bahasa dan nilai.

Berdasarkan hasil wawancara awal dengan pengelola panti asuhan dan beberapa anak panti pada tanggal 29 Nopember 2019 di Panti Asuhan menunjukkan bahwa ada sebagian anak panti yang masih merasa kurang betah , kurang nyaman tinggal di tempat yang baru meskipun sudah cukup lama tinggal di panti. Pihak panti asuhan sendiri sudah memfasilitasi semua kebutuhan dengan memadai, kehidupan yang layaknya seperti keluarga dan lebih dari sebelum tinggal di panti serta membiayai sekolah anak-anak panti serta kegiatan belajar , mengaji dan perawatan kesehatan. Namun masih Terlihat pula ada yang kurang memiliki motivasi dalam melakukan aktivitas sehari-harinya dan interaksi, kerjasama serta komunikasinya pun ada yang masih sangat kurang sehingga sering terjadi kesalahpahaman diantara teman-teman panti dan pengelola panti. Menurut Harriadi (2011;27) menyebutkan ada tiga makna tentang kohesivitas kelompok yaitu pertama ketertarikan pada kelompok termasuk ttidak ingin 
meninggalkan kelompoknya. Kedua moral dan tingkatan motivasi anggota kelompok dan ketiga koordinasi dan kerjasama anggota kelompok. Dalam hal kohesi umumnya menunjuk pada tingkatan yang anggota kelompok termotivasi untuk tetap tinggal di dalam kelompok. anggota kelompok pada kelompok yang kohesinya tinggi lebih enengik di dalam aktivitas kelompok, jarang absen dalam pertemuan kelompok dan merasa senang apabila kelompok berhasil dan bersedih apabila kelompoknya gagal.

Menurut Festinger, Schacter dan Back (dalam Meinarno \& Sarwono,2018,221) mengemukakan bahwa kohesivitas dipengaruhi oleh kemenarikan kelompok dan anggotanya, interaksi sosial dan sejauhmana kelompok bisa memenuhi kebutuhan atau tujuan individu. terbentuknya kohesivitas selanjutnya akan mempengaruhi tingkah laku anggotanya. Yang terjadi pada anak-anak panti asuhan dalam masalah interaksi sosialnya baik dengan teman sepanti maupun dengan pengelola panti serta lingkungan panti tersebut adalah cenderung kurang dalam berkomunikasi menyampaikan apa saja yang memang perlu untuk disampaikan. Anak-anak panti kebanyakan cenderung diam dan pasif atas apa yang seharusnya dikomunikasikan.

Kelompok yang memiliki kohesivitas yang tinggi biasanya terdiri dari individu yang termotivasi untuk membangun kebersamaan dan cenderung memiliki aktivitas kelompok yang efektif, anggotanya kooperatif dan akrab serta saling menghargai antara satu dengan yang lainnya untuk mencapai tujuan, namun apabila terjadi penghindaran biasanya karena rendahnya tingkat keakraban. Kelompok yang kohesivitasnya rendah tidak memiliki ketertarikan interpersonal diantara anggotanya. Biasanya ada rasa saling bermusuhan dan agresif dan justru ada perasaan senang ketika anggota lain berbuat kesalahan ( Hariadi;2011,29-30). Fakta yang ditemukan di lapangan menunjukkan bahwa meski panti asuhan sudah memberikan fasilitas yang memadai dan terbentuk seperti keluarga pada umumnya dengan memberikan pola asuh yang baik untuk anak-anak panti, namun anak-anak panti masih menujukkan cenderung kurang kohesif dan kurang dalam interaksi sosialnya sehingga hal ini bertolak belakang dengan teorinya yang menyampaikan bahwa semakin baik interaksi sosialnya maka semakin tinggi kohesivitas kelompoknya. Dengan demikian peneliti ingin mengetahui apakah ada hubungan antara interaksi sosial dengan kohesivitas kelompok pada anak-anak panti asuhan.

\section{Kohesivitas Kelompok}

Kohesivitas kelompok menurut Meinarno dan Sarwono (2018;220) adalah faktor-faktor yang dimiliki kelompok yang membuat anggota kelompok tetap menjadi anggota sehingga terbentuklah kelompok. kohesivitas penting bagi kelompok karena yang menyatukan beragam anggota menjadi satu kelompok. Tingginya kohesivitas kelompok berhubungan dengan 
konformitas anggota terhadap norma kelompok, kemampuan anggota untuk menitikberatkan pada persamaan sebagai anggota kelompok, meningkatnya komunikasi di dalam kelompok dan meningkatnya rasa suka terhadap anggota kelompok.hal ini senada dengan pendapat Hariadi (2011;27) yang mengatakan bahwa kohesivitas kelompok adalah tingkatan yang menunjukan anggota kelompok saling tertarik satu dengan yang lainnya.

Kohesi kelompok yaitu perhatian anggota kelompok, bagaimana anggota kelompok saling menyukai satu dengan yang lain . dalam kelompok yang berlangsung lama , para anggota lebih tertarik pada kelompok tersebut daripada kelompok yang lain dan juga adanya rasa saling tertarik di antara para anggotanya. Kesamaan sikap , nilai-nilai, sifat-sifat pribadi dan juga sifatsifat demografis akan merupakan pendukung tingginya tingkat kohesi kelompok (Walgito,2003)

Berdasarkan pendapat beberapa tokoh sebagai anggota dapat disimpulkan bahwa kohesivitas kelompok adalah ketertarikan anggota kelompok sehingga termotivasi untuk tetap bertahan didalam kelompok serta bekerjasama dalam mencapai tujuan bersama.

Adapun dimensi-dimensi Kohesivitas Kelompok menurut Forsyth (2010;118-121) mengemukakan bahwa ada empat dimensi kohesivitas kelompok yaitu (:a). Kekuatan Sosial yaitu Keseluruhan dari dorongan yang dilakukan oleh individu dalam kelompok untuk tetap berada dalam kelompoknya. dorongan yang menjadikan anggota kelompok selalu berhubungan dan berkumpul dari anggota tersebut membuat mereka bersatu. (b). Kesatuan dalam kelompok yaitu perasaan saling memiliki terhadap kelompoknya dan memiliki perasaan moral yang berhubungan dengan keanggotaannya dalam kelompok. setiap individu dalam kelompok merasa kelompok adalah sebuah keluarga, tim dan komunitasnya serta memiliki perasaan kebersamaan.(c). Daya Tarik yaitu individu akan lebih tertarik melihat dari segi kelompok kerjanya sendiri daripada melihat dari anggotanya secara specifik (d). Kerjasama Kelompok yaitu Individu memiliki keinginan yang lebih besar untuk bekerjasama untuk mencapai tujuan kelompok

Sedangkan ,menurut Cota (dalamHariadi,2011;28) menyatakan bahwa kohesivitas melibatkan dua dimensi primer yaitu :(a). Tugas Sosial yaitu dimensi yang berkaitan dengan individu tertarik pada tugas kelompok atau dalam hubungan sosial(b). Individu - Group yaitu dimensi ini berkaitan dengan komitmen individu pada kelompok atau anggota yang lain.

Berdasarkan pendapat tokoh tersebut maka dapat disimpulkan bahwa dimensi-dimensi kohesivitas kelompok adalah kekuatan sosial, kesatuan dalam kelompok, daya tarik dan kerjasama kelompok.

Sedangkan faktor-faktor yang mempengaruhi kohesivitas kelompok menurut Festinger, Schacter dan Back (dalam Meinarno \& Sarwono,2018,221) adalah : kemenarikan kelompok 
kemenarikan anggotanya, interaksi sosial dan tujuan individu yang membutuhkan bantuan orang lain.

Hal ini didukung oleh Widyastuti $(2014 ; 140)$ yang mengemukakan bahwa kohesivitas kelompok diawali dengan ketertarikan terhadap kelompok dan anggota kelompok, dilanjutkan dengan interaksi sosial dan tujuan-tujuan pribadi yang menuntut ketergantungan.

Menurut Cota (dalam Hariadi;28) faktor yang mempengaruhi kohesivitas antara lain:((a)sejumlah usaha yang diperlukan untuk kelompok, biaya yang besar untuk masuk kelompok menyebabkan ketertarikan anggota menjadi lebih besar(b).adanya ancaman dari luar atau kompetisi (c) besarnya kelompok, pada kelompok yang keil cenderung lebih kohesif.

Lott \& Lott ( dalam widyastuti,2014;147 ) kohesivitas kelompok dipengaruhi oleh (a). hubungan antar relatif sukarela antara orang-orang yang tidak terlalu jauh berbeda dalam hal=hal yang menjauhkan antarpribadi (b) hubungan kerjasama atau kompetisi yang masih dalam batas yang sesuai norma (c) saling menerima (d)adanya bahaya ancaman dari luar yang harus dihadapi bersama, (e) status yang homogen (f) perilaku dan sifat-sifat pribadi yang berguna untuk memenuhi fungsi kelompok (g) Sikap, nilai-nilai dan latarbelakang yang sama dan kepribadian yang saling mengisi, (h) adanya kebiasaan dan inisiasi yang tidak menyenangkan.

Berdasarkan pendapat para tokoh tersebut maka dapat disimpulkan bahwa faktorfaktor yang mempengaruhi kohesivitas kelompok adalah ketertarikan terhadap kelompok dan anggota, interaksi sosial dan tujuan-tujuan individu akan ketergantungan.

\section{Interaksi Sosial}

Interaksi sosial merupakan hubungan-hubungan sosial yang dinamis, yang menyangkut hubungan antara orang peroranganan, antar kelompok manusia, maupun antara orang perorangan dengan kelompok manusia (Hariadi,2011;36) Dinamis artinya hubungan yang dilakukan oleh individu atau kelompok dengan pihak lain tidaklah statis, monoton dan sebagainya, melainkan akan selalu mengalami dinamika sesuai dengan kebutuhan. Interaksi sesungguhnya adalah suatu bentuk dari saling ketergantungan. Pendapat ini didukung oleh walgito $(2003,57-58)$ yang mengemukakan bahwa interaksi sosial adalah hubungan antara individu satu dengan individu yang lain, individu satu dapat mempengaruhi individu lain atau sebaliknya. Jadi terdapat adanya hubungan yang saling timbal balik.

Gerungan (2004;62) mengemukakan bahwa interaksi sosial adalah suatu hubungan antara dua atau lebih individu manusia, dimana kelakuan individu satu mempengaruhi, mengubah atau memperbaiki kelakuan individu yang lain atau sebaliknya. 
Berdasarkan pendapat para tokoh dapat disimpulkan bahwa interaksi sosial adalah hubungan timbal balik antara individu satu dengan individu yang lain ataupun individu dengan kelompok, yang saling mempengaruhi, mengubah dan memperbaiki.

Ciri-ciri Interaksi Sosial (a)Terdapat pelaku sosial yang lebih dari 1 orang. Proses social interactions hanya dapat terjadi ketika terdapat lebih dari satu orang. (b) Terjadi proses komunikasi antar pelaku sosial dengan memakai simbol - simbol. Komunikasi antar pelaku interaksi dapat dilakukan dengan cara lisan, isyarat, dan gestur tubuh.(c). Terdapat dimensi waktu (masa lampau, kini, masa depan) yang bisa menentukan sifat aksi yang sedang berlangsung. Dengan kata lain proses social interactions pernah terjadi di masa lalu, masa kini,dan juga pada masa yang akan datang. (d) Interaksi dilakukan karena ada tujuan-tujuan tertentu yang ingin dicapai

Menurut Herimanto danWinarno ( dalam Panggabean,2017;107) mengatakan interaksi sosial memiliki ciri-ciri yaitu:((a). Pelakunya lebih dari satu orang (b). Ada komunikasi antar pelaku melalui kontak sosial, (c). Memiliki maksud dan tujuan, terlepas dari sama atau tidaknya tujuan tersebut dengan yang diperkirakan oleh pelaku (d). Ada dimensi waktu yang menentukan sikap aksi yang sedang berlangsung.

Dari beberapa pendapat dapat disimpulkan ciri-ciri interaksi sosial adalah pelaku lebih dari satu orang, ada komunikasi antar pelaku, ada dimensi waktu dan ada tujuan-tujuan tertentu.

\section{Jenis Kelamin}

Jenis Kelamin adalah bawaan sejak lahir yang mengacu pada kondisi fisik dari biologis pria dan wanita. Jenis kelamin dan gender sudah tentu berbeda, kalau jenis kelamin itu sesuatu yang sudah kodratnya ata diciptakan langsung dari Tuhan yang aslinya sudah tidak diubah lagi. sedangkan gender itu cara berpikirnya seseorang apa yang sudah dipercaya . Gender adalah peran perilaku yang dibangun secara sosial terhadap suatu jenis kelamin.

Hipotesis yang diajukan dalam penelitian ini adalah sebagai berikut :

a. Ada hubungan antara interaksi sosial dengan kohesivitas kelompok pada anak-anak panti asuhan.. Semakin baik interaksi sosialnya maka semakin tinggi kohesivitas kelompoknya dan juga sebaliknya, semakin kurang baik interaksi sosialnya maka semakin rendah kohesivitas kelompoknya pada anak-anak panti asuhan tersebut.

b. Ada perbedaan kohesivitas kelompok antara anak panti asuhan perempuan dan anak panti asuhan laki-laki.

\section{Metode}


Metode yang digunakan dalam penelitian ini adalah metode kuantitatif. Dengan variabel tergantungnya kohesivitas kelompok dan variabel bebasnya interaksi sosial dan jenis kelamin. Populasi yang akan diambil dalam penelitian ini adalah anak-anak panti asuhan dengan karakteristik subyeknya adalah anak panti asuhan yang sudah tinggal di panti asuhan minimal 6 bulan dengan pertimbangan sudah melalui proses adaptasi dengan lingkungan baru di panti.

Teknik sampling yang digunakan adalah sampling jenuh. Pengumpulan datanya menggunakan skala yaitu skala kohesivitas kelompok dan skala interaksi sosial.

Metode analisis data dalam penelitian ini menggunakan teknik korelasi korelasi Spearman"s rho dan Mann-Whitney Test untuk membuktikan hipotesis kedua apakah ada perbedaan kohesivitas kelompok antara anak panti perempuan dengan anak panti yang lakilaki.

\section{Hasil}

Berdasarkan hasil uji hipotesis pertama dalam penelitian ini menunjukkan bahwa ada hubungan antara interaksi sosial dengan kohesivitas kelompok. Semakin baik interaksi sosialnya maka semakin tinggi pula kohesivitas kelompoknya.dan sebaliknya sehingga hipotesis dalam penelitian ini diterima. sedangkan hasil uji hipotesis kedua yang menyatakan bahwa ada perbedaan kohesivitas antara anak panti perempuan dan anak panti laki-laki menunjukkan data bahwa $U=60,000, Z=-1,886$ dan $p=0,059(p<0,05)$ sehingga hipotesis ditolak yang berarti tidak ada perbedaan kohesivitas antara anak panti perempuan dan anak panti laki-laki.

Hasil penelitian ini mendukung pendapat yang diutarakan oleh Menurut Harriadi (2011;27) menyebutkan ada tiga makna tentang kohesivitas kelompok yaitu pertama ketertarikan pada kelompok termasuk ttidak ingin meninggalkan kelompoknya. Kedua moral dan tingkatan motivasi anggota kelompok dan ketiga koordinasi dan kerjasama anggota kelompok. Dalam hal kohesi umumnya menunjuk pada tingkatan yang anggota kelompok termotivasi untuk tetap tinggal di dalam kelompok. anggota kelompok pada kelompok yang kohesinya tinggi lebih enengik di dalam aktivitas kelompok, jarang absen dalam pertemuan kelompok dan merasa senang apabila kelompok berhasil dan bersedih apabila kelompoknya gagal.

Menurut Festinger, Schacter dan Back (dalam Meinarno \& Sarwono,2018,221) mengemukakan bahwa kohesivitas dipengaruhi oleh kemenarikan kelompok dan anggotanya, interaksi sosial dan sejauhmana kelompok bisa memenuhi kebutuhan atau tujuan individu. terbentuknya kohesivitas selanjutnya akan mempengaruhi tingkah laku anggotanya. Kelompok yang memiliki kohesivitas yang tinggi biasanya terdiri dari individu yang termotivasi untuk membangun kebersamaan dan cenderung memiliki aktivitas kelompok yang efektif, anggotanya 
kooperatif dan akrab serta saling menghargai antara satu dengan yang lainnya untuk mencapai tujuan, namun apabila terjadi penghindaran biasanya karena rendahnya tingkat keakraban. Kelompok yang kohesivitasnya rendah tidak memiliki ketertarikan interpersonal diantara anggotanya. Biasanya ada rasa saling bermusuhan dan agresif dan justru ada perasaan senang ketika anggota lain berbuat kesalahan ( Hariadi;2011,29-30).

Hipotesis yang kedua dalam penelitian ini tidak terima. hal ini berarti tidak ada perbedaan kohesivitas antara anak-anak panti peempuan dan laki-laki. Kelompok yang memiliki kohesivitas yang tinggi biasanya terdiri dari individu yang termotivasi untuk membangun kebersamaan dan cenderung memiliki aktivitas kelompok yang efektif, anggotanya kooperatif dan akrab serta saling menghargai antara satu dengan yang lainnya untuk mencapai tujuan, namun apabila terjadi penghindaran biasanya karena rendahnya tingkat keakraban. Kelompok yang kohesivitasnya rendah tidak memiliki ketertarikan interpersonal diantara anggotanya. Biasanya ada rasa saling bermusuhan dan agresif dan justru ada perasaan senang ketika anggota lain berbuat kesalahan ( Hariadi;2011,29-30).

Berdasarkan hasil data penelitian yang diperoleh, varibel kohesivitas kelompok memperoleh mean empirik sebesar 75,23 dan mean hipotetik sebesar 57,5 dan standar deviasi hipotetik sebesar 11,5 . Mean empirik variabel kohesivitas kelompokl pada area (+) 1SD hingga (+) 2SD. Hal ini mengindikasikan bahwa kohesivitas kelompok berada pada kategori tinggi yaitu, bahwa anak-anak panti merasa kohesif untuk tinggal di lingkungan rumah panti.

Pada variabel interaksi sosial memperoleh mean empirik sebesar 64,03 dan mean hipotetik sebesar 47,5 dan standar deviasi hipotetik sebesar 9,5 . Mean empirik variabel interaksi sosial pada area (+) 1SD hingga (+) 2SD Hal ini mengindikasikan bahwa anak-anak pantii masih dapat menunjukkan interaksi sosialnya dengan cukup tinggi.

Pengaruh interaksi sosial terhadap kohesivitas kelompok tetap ada meskipun hanya memberikan sedikit sumbangannya yaitu 15,2 \% . Sumbangan efektif variabel interaksi sosial terhadap kohesivitas kelompok adalah $15,2 \%$ dan sisanya sebesar $84,4 \%$ dari variabel lain seperti motivasi, komunikasi.

\section{Simpulan}

Berdasarkan hasil uji hipotesis pertama dalam penelitian ini menunjukkan bahwa ada hubungan antara interaksi sosial dengan kohesivitas kelompok. Semakin baik interaksi sosialnya maka semakin tinggi pula kohesivitas kelompoknya.dan sebaliknya sehingga hipotesis dalam penelitian ini diterima. sedangkan hasil uji hipotesis kedua yang menyatakan bahwa ada perbedaan kohesivitas antara anak panti perempuan dan anak panti laki-laki menunjukkan data bahwa $U=60,000, Z=-1,886$ dan $p=0,059(p<0,05)$ sehingga hipotesis 
ditolak yang berarti tidak ada perbedaan kohesivitas antara anak panti perempuan dan anak panti laki-laki.

\section{Kepustakaan}

Faturochman, 2006. Pengantar Psikologi Sosial. Yogyakarta : Pustaka.

Forsyth, D. R,. 2006. Group Dynamics. (International Student Edition) Pustaka Belmont. CA: Thomson Wadsworth Publishing.

Gerungan. WA. (2004) . Psikologi Sosial . Bandung : PT Refika Aditama.

Hariadi, S,Sunarru. 2011. Dinamika Kelompok. Yogyakarta: Pascasarjana UGM.

Meinarno, A. Eko \& Sarwono, W.Sarlito. 2018. Psikologi Sosial. Edisi 2. Jakarta : Salemba Humanika.

Mercer,J \& Clayton,D. 2012. Psikologi Sosial. Jakarta : Erlangga.

Panggabean,A.P, (2017) Kualitas Interaksi Sosial antara Penjual dan Pembeli di Taman Pintar Book Store Yogyakarta. Indigenous : Jurnal Ilmiah Psikologi. 2(2).

Saam, Zulfan. 2013. Psikologi Konseling. Jakarta : PT.Rajagrafindo Persada.

Taufik. 2012. Empati Pendekatan Psikologi Sosial. Jakarta : PT. Rajagrafindo.

Widyastuti, Yeni. 2014. Psikologi Sosial. Yogyakarta : Graha Ilmu.

Walgito, Bimo. 2003. Psikologi Sosial Suatu Pengantar . Yogyakarta : Andi Offset. 